\title{
Implementasi Metode K-Nearest Neighbor Untuk Penentuan Lokasi Pos Hujan Terdekat Dengan Titik Rute Perjalanan Pada Aplikasi Clearroute
}

\author{
Anwar Rosyidi,R.V Hari Ginardi, dan Abdul Munif \\ Departemen Teknik Informatika, Fakultas Teknologi Informasi, Institut Teknologi Sepuluh Nopember \\ (ITS) \\ e-mail: hari@its.ac.id
}

\begin{abstract}
Abstrak-Clearroute adalah aplikasi yang dibangun untuk memudahkan seseorang mengetahui informasi cuaca pada rute perjalanan yang akan dilaluinya. Aplikasi ini dibangun untuk platform perangkat bergerak yang memiliki fungsi-fungsi untuk memudahkan seseorang mencari informasi cuaca untuk perjalanannya.Pada aplikasi perangkat bergerak tersebut, diperlukan sebuah sistem web service yang dapat melakukan pengolahan data. Seperti pengolahan data untuk menentukan lokasi pos hujan terdekat dengan rute perjalanan pengguna. Pada sistem yang dibangun ini digunakan algoritma K-Nearest Neighbor untuk menentukan klasifikasi cuaca yang dimiliki oleh rute yang akan dilalui oleh pengguna. Kemudian sistem ini memanfaatkan Laravel 5.4 sebagai kerangka kerja pemrograman. Pengujian pada sistem ini dilakukan dengan cara melakukan permintaan informasi cuaca kepada sistem, mencoba melakukan ekstraksi data cuaca dari BMKG.Pengujian tersebut dilakukan untuk mengetahui keberhasilan sistem dalam menangani permintaan dan pengolahan data yang diminta oleh aplikasi perangkat bergerak Clearroute. Dari hasi pengujian, sistem yang telah dirancang dan diimplementasikan telah memenuhi segala kebutuhan pengolahan data pada aplikasi Clearroute
\end{abstract}

Kata Kunci-Clearroute, Pos Hujan, K-Nearest Neighbor.

\section{PENDAHULUAN}

$\mathrm{D}$ ALAM setiap perjalanan tentu banyak pertimbangan yang akan diperhitungkan untuk melaksanakan perjalanan tersebut, beberapa diantaranya adalah rute yang dilalui dan cuaca. Rute merupakan alur dan arah yang akan dilalui untuk mencapai tempat tujuan, dan cuaca adalah keadaan udara pada saat tertentu dan di wilayah tertentu yang relatif sempit (tidak luas) dan pada jangka waktu yang singkat.

Dewasa kini pengguna tidak perlu repot-repot memikirkan rute mana yang harus diambil, karena hal tersebut sudah dapat dibuat secara langsung oleh komputer. Komputer menentukan rute berdasarkan pilihan-pilihan yang sudah diatur oleh pengguna atau pengembangnya, dan semua pilihan itu diolah menggunakan suatu Algoritma yang dirasa pengembang merupakan algoritma terbaik untuk menentukan rute yang diinginkan.

Di Indonesia, terdapat badan yang secara resmi memiliki tugas untuk mengawasi dan memberikan berita mengenai cuaca yang sedang berlangsung dan akan terjadi, yaitu Badan Meteorologi Klimatologi dan Geofisika (BMKG). BMKG secara real time selalu memperbaharui berita cuaca yang ada, agar dapat dilihat oleh masyarakat umum. Dan untuk mendapatkan data infrormasi cuaca BMKG kota Surabaya menggunakan acuan beberapa Pos Hujan yang biasanya merupakan kantor desa atau tempat umum besar lainnya untuk memberikan informasi mengenai cuaca di sekitar pos hujan tersebut.

Pada paper ini ini, Algoritma yang digunakan untuk menentukan klasifikasi kondisi cuaca adalah K-Nearest Neighbor. K-Nearest Neighbor (KNN) adalah sebuah metode untuk melakukan klasifikasi terhadap suatu objek berdasarkan data pembelajaran yang memiliki jarak paling dekat dengan objek tersebut.

\section{MATERI DAN METODE}

Gambar 1 menunjukan gambaran umum dari aplikasi perangkat bergerak yang dibangun. Pertama aplikasi akan terhubung ke dalam API Mapbox untuk mendapatkan data graph dari peta yang akan diimplementasikan dalam menampilkan rute perjalanan pada aplikasi yang yang dibangun. Selanjutnya aplikasi akan terhubung ke dalam web service yang mengolah data cuaca yang didapatkan dari lembaga pengamatan cuaca pemerintah. Gambar 2. akan menjelaskan mekanisme dari pengolahan seluruh proses berjalanannya sistem yang dibangun pada paper ini untuk mendapatkan hasil keluaran yang dibutuhkan oleh aplikasi

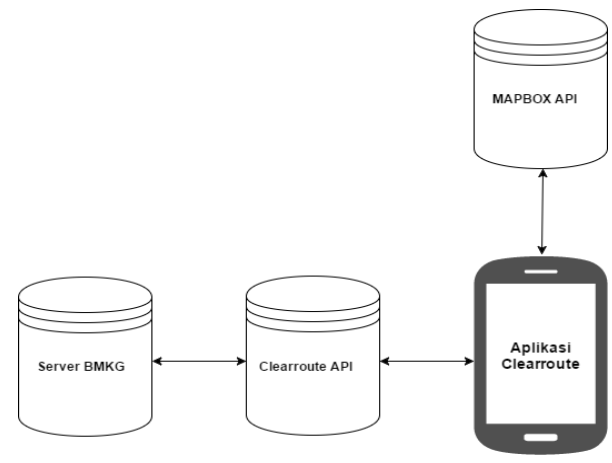

Gambar 1. Arsitektur Sistem 


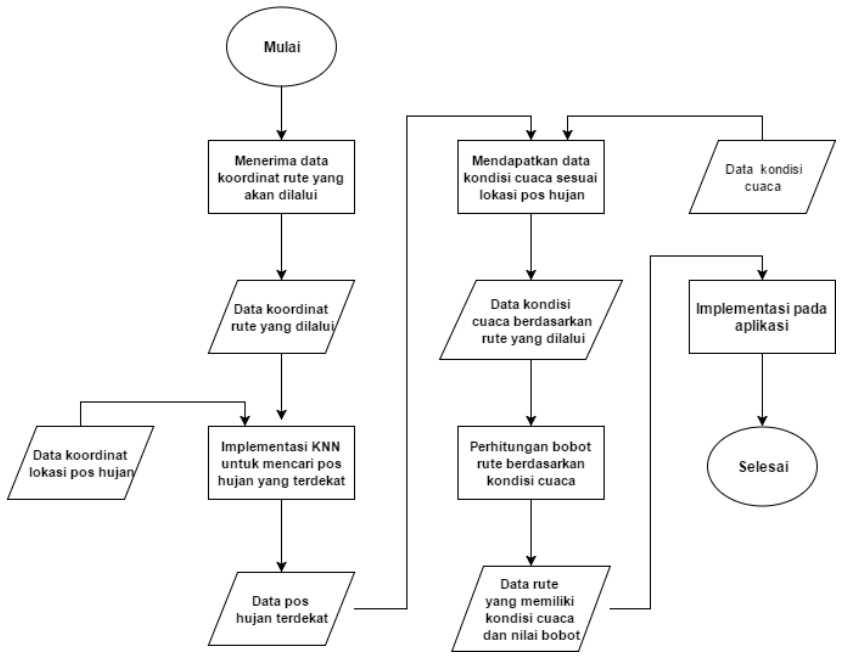

Gambar 2. Desain Umum Sistem

\section{A. Peramalan Cuaca}

Peramalan cuaca adalah suatu cabang aplikasi sains dan teknologi untuk memprediksi kondisi atmosfer pada waktu yang akan datang pada suatu lokasi tertentu. Pada paper ini akan digunakan informasi ramalan cuaca yang dikeluarkan oleh lembaga pengamatan cuaca milik pemerintah Indonesia. Dalam melakukan peramalan cuaca dapat dilakukan secara objektif dan subjektif. Metode subjektif adalah prediksi yang dibuat berdasarakan pertimbangan atau penilaian dari seseorang yang melakukan pengamatan cuaca [1].

Saat ini jenis model ramalan cuaca telah banyak digunakan untuk menghasilkan informasi ramalan cuaca salah satu model cuaca yang banyak digunakan ialah model WRF (Weather Research Forecasting). Model WRF ini menggambarkan kondisi cuaca berdasarkan kondisi atmosfer yang sedang terjadi. Penggambaran kondisi atmosfer oleh

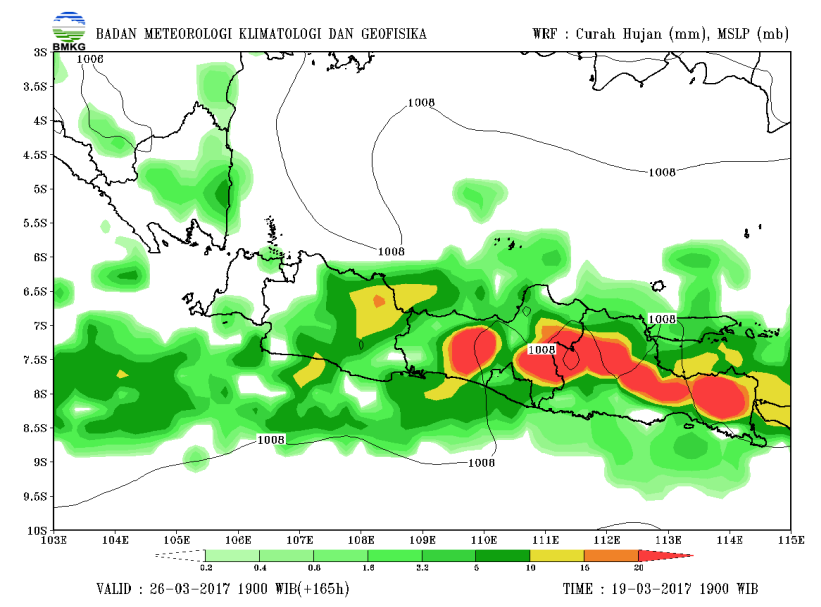

Gambar 3. Weather Research Forecasting Model

WRF langsung digambarkan dalam suatu peta wilayah yang kondisi ramalan cuacanya sedang diamat seperti yang ditunjukan oleh Gambar 3. Saat ini lembaga resmi pemerintah Indonesia yang menangani pengamatan cuaca telah menggunakan model cuaca WRF untuk menampilkan hasil pengamatan ramalan cuaca. Data model WRF yang dikeluarkan memiliki masa berlaku 3 jam sehingga setiap jeda waktu 3 jam model pengamatan WRF akan diperbarui[1].

\section{B. Data Resource}

Sumber data cuaca yang digunakan berasal dari badan meteorologi pemerintah Indonesia. Ada dua jenis data yang digunakan yaitu data ramalan cuaca yang ditunjukan oleh Gambar 3 data cuaca terkini yang ditunjukan oleh Gambar 4. Data ramalan cuaca merupakan data gambar dengan format WRF (Weather Research Forecasting). Dan data cuaca terkini diambil dari data stasiun pengamatan cuaca yang tersebar di seluruh kota Surabaya [2].

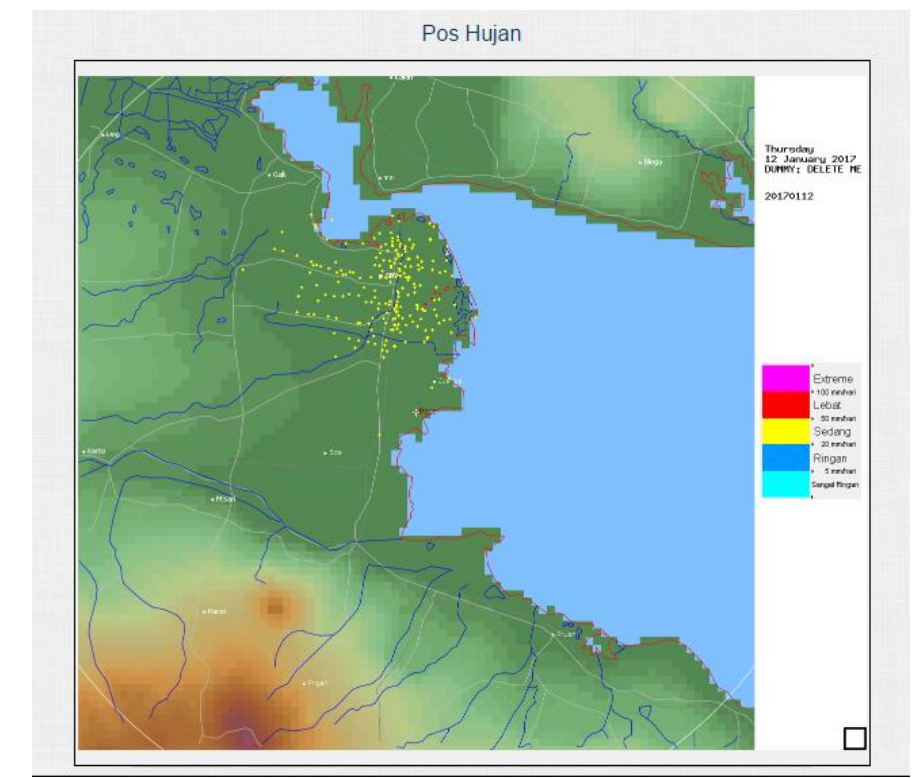

Gambar 4. Data Cuaca Terkini

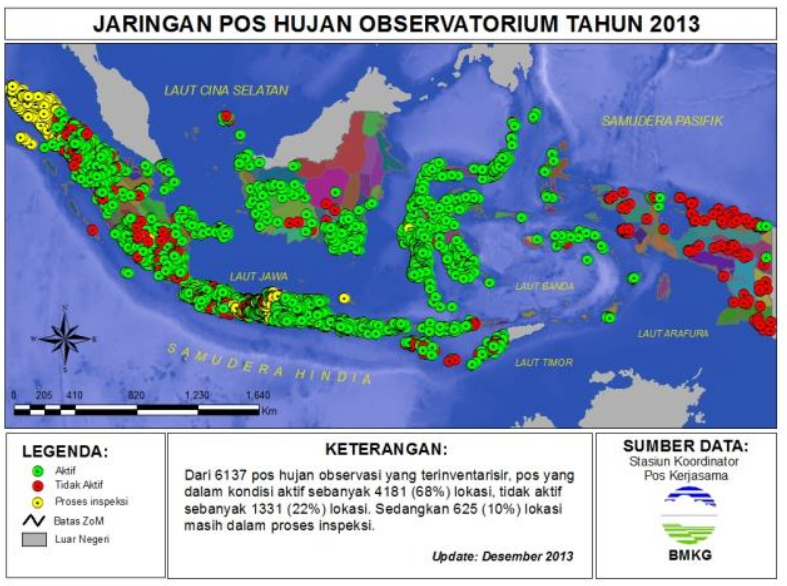

Gambar 5. Pos Hujan BMKG

\section{Pos Hujan BMKG}

Dalam melakukan pengamatan curah hujan BMKG memiliki pos-pos pengamatan curah hujan yang disebut sebagai pos hujan. Untuk kota Surabaya pos hujan yang dimiliki tersebar pada setiap kelurahan atau desa. Fungsi utama dari pos hujan ini ialah merekam curah hujan yang terjadi secara real time. Pos hujan akan melakukan perekaman data setiap 10 menit sekali yang kemudian dikirimkan kepada stasiun pengamatan cuaca induk. Untuk kota Surabaya sendiri 
stasiun pengamatan induk berada di kawansan bandara Juanda Surabaya. Gambar 5 menunjukan peresebaran titik lokasi pos hujan yang dimilki oleh Badan Meteorologi Indonesia pada tahun 2013[2].

\section{K-Nearest Neighbor}

K-Nearest Neighbor (KNN) adalah sebuah metode untuk melakukan klasifikasi terhadap suatu objek berdasarkan data pembelajaran yang memiliki jarak paling dekat dengan objek tersebut. Data pembelajaran akan diproyeksikan ke dalam K ruang berdimensi banyak, yang masing-masing dimensi merepresentasikan fitur dari data. Ruang ini akan dibagi-bagi menjadi suatu bagian berdasarkan klasifikasi yang telah dilakukan terhadap data pembelajaran [3][4].

Langkah-langkah yang dilakukan untuk melakukan metode $K$-Nearest Neighbor ada sebagai berikut:

1. Generate data sampel yang akan digunakan sebagai data training

2. Inisialisasi $\mathrm{K}$ titik sebagai titik-titik pusat (centroids) awal

3. Hitung jarak setiap objek data set dengan data training menggunakan perhitungan Euclidean distance. Rumus untuk menghitung jarak antar dua titik $\left(x_{1}, y_{1}\right)$ sebagai titik data set dengan $\left(x_{2}, y_{2}\right)$ sebagai titik data training ditunjukkan pada (1):

$$
\operatorname{dis}(x, y)=\sqrt{\left(x_{1}-x_{2}\right)^{2}+\left(y_{1}-y_{2}\right)^{2}}
$$

Apabila titik koordinat (x,y) dalam satuan koordinat latitude dan longitude maka terlebih dahulu nilai $(\mathrm{x}, \mathrm{y})$ tersebut diubah ke dalam satuan koordinat Cartesian seperti yang ditunjukkan pada (2) dan (3).

$$
\begin{aligned}
& X=R * \cos (\text { lat }) * \cos (\text { lon }) \\
& Y=R * \cos (\text { lat }) * \sin (\text { lon })
\end{aligned}
$$

\footnotetext{
Keterangan:

$\mathrm{R} \quad=$ Jari-jari bumi $(6371 \mathrm{~km})$.

lat $=$ Nilai latitude .

lon = Nilai longitude .
}

\section{UJI COBA}

Pada bagian ini, dilakukan dua tipe percobaan. Percobaan pertama ialah meneliti akurasi data. Percobaan kedua ialah melakukan percobaan perjalanan dengan beberapa lokasi tujuan yang berbeda.

\section{A. Uji Coba Perhitungan Akurasi Data}

Pada uji coba ini akan dilakukan uji coba terhadap kondisi cuaca pada titik pos hujan dengan beberapa titik pos hujan terdekat lainnya. Hal ini dilakukan untuk mengetahui mengenai akurasi dari data cuaca pos hujan yang akan digunakan oleh sistem. Pada uji ini akan diambil titik pos hujan yang berada pada kecamatan Sukolilo dan kecamatan Wonokromo, dan kecamatan Tandes. Kemudian data yang digunakan ialah data cuaca pada tanggal 16 Januari 2017 pukul 12.00 UTC.

\section{B. Uji Coba Rute Perjalanan}

Pada uji coba ini akan dilakukan uji coba melihat rute perjalanan yang ditampilkan oleh aplikasi. Akan dilakukan dua kali perjalanan dengan kondisi cuaca yang berbeda. Pada rute perjalanan pertama akan dilakukan perjalanan dengan keadaan yang jalan yang cerah dan yang kedua dilakukan perjalanan dengan rute perjalanan pada saat cuaca sedang hujan. Pada eksperimen akan dilihat apakah aplikasi berhasil menunjukan rute perjalanan dengan kondisi cuaca yang akan dilalui oleh pengguna.

\section{HASIL}

Pada bagian akan disampaikan hasil dari uji coba yang dilakukan

\section{A. Perhitungan Akurasi Data}

Dari percobaan yang dilakukan didapatkan nilai akurasi sebesar 73\%. Nilai akurasi ini dihitung dengan menggunakan klasifikasi nilai $\mathrm{K}=3$. Kemudian perhitungan akurasi juga menggunakan confussion matrix sebagai tolok ukur untuk menentukan besaran akurasi data. Hasil perhitungan akurasi menggunakan conffusion matrix dapat dilihat pada Tabel 1 . Dari 60 lokasi pos hujan yang dipilih untuk diuji didapatkan hasil sebagai berikut

$$
\text { akurasi }=\frac{44}{60} * 100 \%=73 \%
$$

Tabel 1.

Perhitungan Akurasi Confussion Matrix

\begin{tabular}{ccccc}
\hline \hline & Cerah & Berawan & Ringan & Lebat \\
\hline Cerah & 2 & 0 & 0 & 0 \\
Berawan & 2 & 10 & 5 & 0 \\
Ringan & 0 & 2 & 19 & 3 \\
Lebat & 0 & 0 & 4 & 13 \\
Total & 4 & 12 & 28 & 16 \\
\hline \hline
\end{tabular}

Gambar 6. Rute Cuaca Cerah

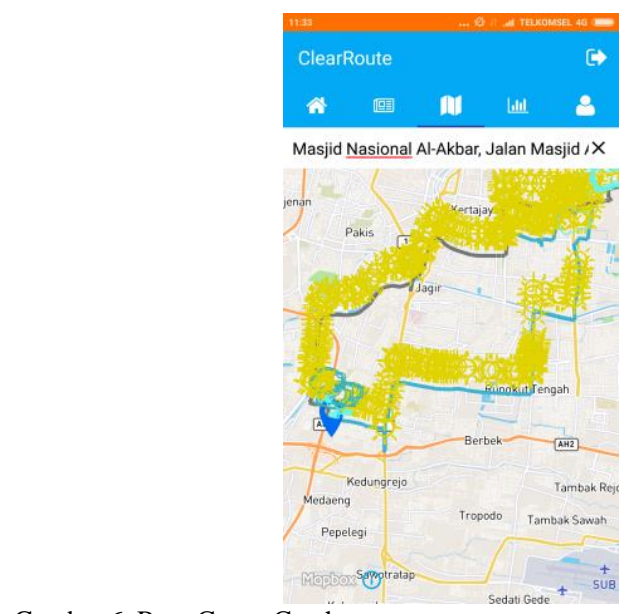

ㄷ)

Gambar 6. Rute Cuaca Cerah 


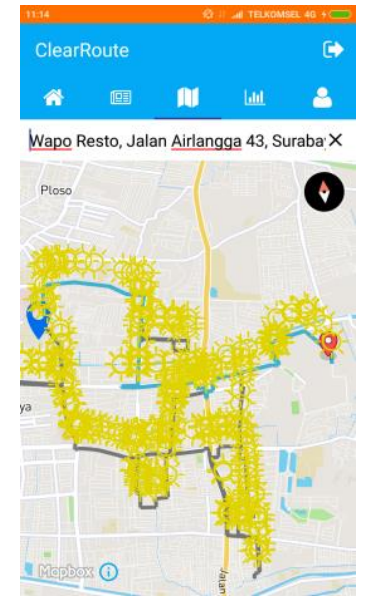

Gambar 7. Rute cuaca Hujan

\section{B. Travel Route}

Gambar 6 menunjukan kondisi rute perjalanan dengan kondisi cuaca cerah dan Gambar 7 menunjukan rute perjalanan yang memiliki kondisi hujan.. Rute perjalanan yang menjadi rekomendasi ialah rute yang memiliki warna biru dan rute alternatif ditunjukan dengan warna hitam. Pemberian rekomendasi rute ini berdasarkan bobot yang dimilki oleh masing-masing rute. Bobot diberikan berdasarkan kondisi cuaca yang akan dilalui.

\section{KESIMPULAN}

Dari hasil uji coba perhitungan response time didapat hasil perbedaan waktu yang besar antara sistem yang belum di optimalisasi dan belum dioptimalisasi. Perbedaan waktu yang didapatkan lebih dari setengah antara hasil yang telah dioptimalisasi dan belum dioptimalisasi. Namun dari data waktu respon server yang didapatkan setelah dilakukan optimaliasi masih berada diatas 4 detik untuk rute yang paling jauh. Hal ini disebabkan oleh belum dioptimalisasinya server yang digunakan untuk mengelola data pencarian rute perjalanan dengan data kondisi cuaca. Kemudian didapatkan juga bahwa sistem yang dibangun telah berhasil menunjukan rute perjalanan dan informasi cuaca yang ada pada rute tersebut. Sistem juga dapat memberikan rekomendasi rute pilihan berdasarkan kondisi cuaca yang dilaluinya.

\section{DAFTAR PUSTAKA}

[1] I. Gustari, T. W. Hadi, S. Hadi, dan F. Renggono, "AKURASI PREDIKSI CURAH HUJAN HARIAN OPERASIONAL DI JABODETABEK: PERBANDINGAN DENGAN MODEL WRF," $J$. Meteorol. Dan Geofis., vol. 13, no. 2, 2012.

[2] “.: Jaringan Pos Hujan - Climate Early Warning System - CEWS BMKG:.” [Daring]. Tersedia pada: http://cews.bmkg.go.id/Sistem_Observasi/Jaringan_Pos_Hujan.bmkg. [Diakses: 01-Mei-2017].

[3] "k-nearest neighbors algorithm - Wikipedia." [Daring]. Tersedia pada: https://en.wikipedia.org/wiki/K-nearest_neighbors_algorithm. [Diakses: 04-Jan-2017].

[4] "Research of Spatial Data Query Optimization Methods Based on KNearest Neighbor Algorithm," ResearchGate. [Daring]. Tersedia pada: https://www.researchgate.net/publication/285618786_Research_of_Spa tial_Data_Query_Optimization_Methods_Based_on_KNearest_Neighbor_Algorithm. [Diakses: 04-Jul-2017]. 